\title{
Romanian Contribution to the Study of Polar Motion
}

\author{
Magda Stavinschi \\ Astronomical Institute of the Romanian Academy, Str. Cuţitul de \\ Argint 5, RO-75212 Bucharest, Romania
}

\section{Introduction}

Romanian astronomy has an old tradition, which is rather less well-known abroad. More known perhaps are the Dacian sanctuary of Sarmizegetusa Regia, very similar to that of Stonehenge, or the contribution of the monk Dionysius Exiguus (born at Tomis, in Dobrogea) to the initiation of the Christian Era. But one of the most important applications of the astronomical knowledge was coordinate determination. It is interesting to remark that the development of astronomy since the 16th century followed closely the advances of accuracy in estimating the coordinates of the main localities.

\section{Geographic Coordinates}

A first mention in this context was made by Hrisant Notara, who had become Patriarch of Jerusalem. Educated at the court of Constantin Brâncoveanu, prince of Wallachia, he was sent to study in the most important cultural centers of that time, Padova, Constantinopole, Moscow, and of course Paris, where he worked with G. D. Cassini. In Paris, he published Introductio ad geographiam et sphaeram (1716), where one can find two special chapters on longitudes and latitudes on the Earth; at the end of the volume is given the catalogue of longitudes and latitudes for 239 localities, coordinates probably compiled from other catalogues. Here appear for the first time the coordinates of Bucharest (long. $47^{\circ} 0$; lat. 45:0) and Târgovişte (long. 48:0; lat. 46.0), probably referred to the meridian of Iron Island, considered for a long time as the origin of longitudes.

An important presence on the Romanian territory is that of Giuseppe Boscowich (1711-1787), Italian mathematician and philosopher, who performed coordinate determinations in Romania. It is to him that Romania owes the oldest latitude determinations performed at Galaţi and Iaşi. They are recorded in Journal d'un voyage de Constantinople en Pologne fait à la suite de Son Excellence Mr. Jaq. Porter, ambassadeur d'Angleterre, par le R. P. Boscowich de la Compagne de Jésus, en 1762, Lausanne, 1772. To determine the latitude and longitude of the port Galaţi, he had at his disposal "only a quadrant with reflection of one foot and a half (about $45 \mathrm{~cm}$ ), by means of which one easily determines the Sun's height on the sea, where the horizon is well determined, but which cannot serve in places where the inequality of the ground prevents from horizon determining, unless we resort to reflection in the water, uniting the two images of the Sun, in the water and in the mirror of the instrument. Acting in this way makes the rectification of the quadrant very difficult when the Sun's 
height is greater than 45 degrees, as was the case. Therefore I used the surface of the Danube, which was not broad enough southward in this site to allow the determination of the horizon, although I had bent over its surface so much that the lower part of the instrument was at the water level." For the longitude, he took, with the same instrument, several distances between the Moon and the Sun, after adjusting a clock to strike the second, by means of the Sun's height determined through its reflection in the water. Boscowich's results are good enough, if we take into account under what conditions and with what means he worked.

During the same period (1771-1772) the Academy of Sciences of Petersburg has charged the astronomer Ivan Islenieff with the determination of the geographic coordinates of the following localities: Bender, Acherman, Chilia Nouă, Ismail, Bucharest, Focşani, Iaşi and Brăila, all situated at that time in Romanian territory.

The Russian astronomer Stefan Rumowski published the memoir that contains these observations under the title Determinatio Longitudinis et Latitudinis quorundam Moldaviae et Valachiae locorum deducta ex observationibus IOHANNE ISLENIEFF institutis in Novi Commentarii Academiae Scientiarum imperialis Petropolitanae, tome XVIII, 1763. Islenieff provided all the details concerning his observations and the manner of calculation. The longitude was determined by means of Jupiter's Galilean satellites; this was a fashionable method at that time. Due to the penumbral and umbral cones, the eclipses of these satellites do not occur instantaneously. It is well known that the moment of immersion or emmersion of a satellite depends on the atmospheric situation and on the power of the instrument. One estimates that the error in determining a difference of longitude by this method can reach $40 \mathrm{~s}$, an acceptable approximation for that epoch. To observe the Jovian satellites, Islenieff used a telescope of 10 feet length, constructed by Dollond. The latitude was determined by observing the meridian heights of the Sun and stars by means of a quadrant of reflection. The results were published by De Baur, lieutenant general and general marshal of the Russian army, in Mémoires historiques et géographiques sur la Valachie, avec un Prospectus d'un Atlas géographique et militaire de la dernière guerre entre la Russie et la Porte Ottomane publiés par Monsieur de $B^{* * *}$, Frankfurt, Leipzig, 1778.

One year later Connaissance des Temps published for first time the coordinates of a Romanian site, in the volume for 1779. Bucharest's coordinates are: latitude: $44^{\circ} 26^{\prime} 45^{\prime \prime} \mathrm{N}$, longitude: $23^{\circ} 48^{\prime} 0^{\prime \prime} \mathrm{E}$ in arc units (or $1 \mathrm{~h} 25 \mathrm{~m} 12 \mathrm{~s}$ in time units). There are just the values provided by General De Baur's book, printed in Lausanne in 1778.

New determinations were performed by Russian officers in the years 1828 1832 , when they also dealt with the determination of the magnetic declination (see Volume VIII of Becquerel's Traité de l'électricité et du magnétisme, 1836). Other works performed by the Russians on the Romanian territories were Memoirs of the military topographic store, edited by the Director of the deposit, Lieutenant General Schubert, by order of His Imperial Majesty, 1837; Astronomische Ortsbestimmungen in der Europäischen Türkei, in Kaukasien und Klein-Asien, nach den von den Officieren des kaiserlichen Generalstabes in den Jahren 1828 bis 1832 angelstellten astronomischen Beobachtungen, abgeleitet und zusammengestellten von..., St. Petersburg, 1845, by F. G. W. Struve; Ex- 
posée des travaux astronomiques et géodésiques exécutés en Russie dans un but géographique jusqu'à l'année 1855, par le Général d'infanterie... , St. Petersburg, 1858, by F. G. de Schubert; Kataloga trigonometricheskikha $i$ astronomicheskikha punktova, St. Petersburg, 1863, by Lieutenant General Blaramberg.

In 1855-1857 the Austrian Headquarters, together with General Barozzi and some graduates of the first promotion of the Military School, as Generals Borănescu, Slăniceanu, and others, have determined the longitudes and latitudes of 120 points belonging to the chain of the Danube, Ialomiţa, Dâmboviţa, Olt, and Dobrogea.

The Austrian astronomer Karl Kreil performed determinations of coordinates in Romania during 1858 , in order to complete the work of the German Lamont by composing the magnetic map of the South-Eastern Europe. His determinations were made at Calafat, Bucharest, Galaţi, Sulina, Şerpilor Island.

The 19th volume of the famous Catalogue of Carl L. von Littrow Gehlers Physikalisches Wörterbuch, issued in 1854, contains, under the title Verzeichniss geographischer Ortsbestimmungen, the most complete catalogue of geographic coordinates published up to that time. For Romania, it provides the coordinates of 26 localities. Bucharest, for instance, is mentioned as having the latitude $44^{\circ}$ $25^{\prime} 39^{\prime \prime}$, and the longitude measured from Paris $23^{\circ} 45^{\prime} 0^{\prime \prime}$ or $1 \mathrm{~h} 35 \mathrm{~m} 0 \mathrm{~s}$, on the Bishopic Hill, close to the actual Astronomical Observatory.

Th. von Oppolzer and E. W. Weiss from the University of Vienna went to Iaşi to observe Mercury's transit across the Sun's disk (9 December 1874). On this occasion, they also determined the longitude (by exchanges of electric signals between Iaşi and Vienna) and the latitude (by measuring zenithal distances in the neighborhood of the meridian).

One of the most important Romanian astronomers of the 19th century was Constantin Căpităneanu (1844-1893). He worked at Observatoire de Paris and at the Topographic Institute of Naples. He achieved the map ordered by the War Store, which later became the Geographic Institute of the Army. In 1875, he determined, along with Austrian astronomers, the difference of longitude between Iaşi and Chernovtsy. He had a transit instrument for longitude determinations, a telescope for the positioning in the first vertical in view of latitude determinations, three chronometers, a chronograph, electric devices, and two refractors. The longitude of Iaşi was determined with respect to the origin accepted at that time: the meridian of Paris. It was also compared with the longitudes of Nikolaev and Chernovtsy (the latter one being, in its turn, compared with that of Krakow).

The observational results were published by C. Căpităneanu and F. Kühnert, in Romanian and French, in Determination of the Difference of Longitude between Iaşi and Chernovtsy, Bucharest, 1881. This is the first work of observational astronomy performed by a Romanian in his country. Between 3 July and 28 August 1877 , C. Căpităneanu and Samotschnikov determined the differences of longitude Galaţ̧i - Bucharest, Galaţi - Iaşi, and Kishinew - Iaşi, as well as the latitudes of Bucharest, Galaţi, and Iaşi. In October 1877, Savizki and Samotschnikov determined the difference of longitude Bucharest - Sištov. The difference of longitude between Bucharest and Braşov was measured in 1885 . 
Few years later, I. A. Cantacuzino published Longitudes and Latitudes of more than 100 localities from Romania (1891), all reported to the meridian of Paris.

An important step in the geographical coordinates made by astronomical methods was the foundation in Bucharest of the Military Astronomical Observatory in 1894-1895. Two of its important representatives, Major Th. Râmniceanu and Captain Toroceanu determined in 1900 the difference of longitude between Bucharest and Potsdam, after having performed some determinations of latitudes, too.

In 1908 the Astronomical Observatory of Bucharest, the nucleus of the actual Astronomical Institute of the Romanian Academy, was founded. Among the first instruments that were purchased for longitude and latitude determinations, were the meridian circle Steinheil-Prin $(d=19 \mathrm{~cm}, f=235 \mathrm{~cm})$, installed in 1926, a printing chronograph Gautier-Prin, and fundamental pendulums (Leroy for sidereal time, Riefler for mean time), installed under constant temperature and pressure, at the second level of the basement of the Observatory.

Its first participation in an international campaign was that at the World Longitude Operation of October-November 1933. In its final bulletin of 1938 , Bureau International de l'Heure published the list of the 63 observatories that achieved the calculations. Romania was present in that list through the Astronomical Observatory of Bucharest and the Military Geographic Institute. The Astronomical Observatory had an average of 25 receptions of signals per day, and the Military Geographic Institute - 5 receptions/day, as compared with the average of 10 receptions/day for all the Observatories. For this operation, the Observatory was endowed with installations for the reception of time signals constructed by the Romanian engineer Ciril Petrescu.

The Third World Longitude Operation took place within the framework of the International Geophysical Year, 1 July 1957-31 December 1958. In view of this operation, the Astronomical Observatory of Bucharest created a Time Service, for which there was purchased, in 1956, a transit instrument Zeiss $(100 / 1000 \mathrm{~mm})$, endowed with a Horebow-Talcott level for latitude determinations. After an interval of experiments, BIH included the Observatory of Bucharest in its Bulletins, starting with the year 1958. Since 1 April 1958, the time base consisted of the Belin quartz clocks, whereas the time signals were recorded by means of a Belin cylinder chronograph.

The observations were continued regularly after the IGY, the time base being ensured, starting from 1967, by Rohde 6 Schwarz quartz clocks.

\section{Earth Rotation and Polar Motion}

Since 1961, the Observatory of Bucharest was included in the so-called "Mean Observatory", which defined the BIH reference system via its coordinates. The latitude of Bucharest was determined in 1962 as being $44^{\circ} 24^{\prime} 50^{\prime \prime} \mathrm{N}$. In the interval 1959-1989 there were performed studies of the particulars of the transit instrument and about the running of the quartz clocks. Under the direct supervision of Constantin Drâmbă (1907-1997), the Earth's rotation was studied within the more general framework of elastic deformations. Thus, on the basis of the Euler generalized equations, the existence of the Chandler ellipse described 
by the instantaneous pole of the Earth's rotation was theoretically established, and so was the analytical expression of the Chandler period. Starting from the elasticity differential equations written in a rotating frame, converted into global equations, and applied to the Earth (small inertia products), the equations for the trajectory of the instantaneous rotation pole have been determined. The coordinates of the instantaneous pole of inertia along the plane tangent to the Earth's surface have also been determined with the contact point in the mean pole.

The relation between the time variation of the terrestrial potential and the latitude variation for a given point was investigated, establishing the corresponding analytic relationship. Successive positions of the pole of inertia were calculated and reported to the instantaneous pole.

As to the motion of the Earth's pole, a separation of the polhody components for the time sequence 1899-1969 was performed using the IPMS information. The period and amplitude of several components (e.g. the mean Chandler ellipse, the annual and semiannual components, a 0.77-year residual component) have been estimated numerically within the framework of the same studies. Starting from the latitude observations performed in Bucharest by the Talcott method, the motion of the instantaneous rotation pole was investigated. The relative variation curves of the $F$ and $G$ products of inertia, as well as that of the $C$ moment of inertia were determined both numerically and graphically for the Earth's main ellipsoid of inertia, by using BIH and IPMS data. The particular case of the motion of a deformable body having a fixed point was closely examined. Starting from the IPMS data, the shift of the tectonic plates was investigated. The influence of the Earth's variable rotation (via the Lense-Thirring effect) on artificial satellite motion was studied. Also, interesting results about the rotation of the three-axial Earth were obtained using the KAM theory. After 1990 global analyses of the observations performed at Bucharest with the transit instrument were done, especially as regards the long periodic terms of the UT1-TA data.

These results were published mainly in Studii şi cercetări de astronomie and Romanian Astronomical Journal (from 1991), but also in foreign journals.

The results of the astronomical determinations of time performed during this period were sent to: $B I H$ - Bureau International de l'Heure (Paris), IPMS International Polar Motion Service (Mizusawa), Etalonnoe Vremya and Vsemirnoe Vremya (Moscow), IERS - International Earth Rotation Service (Paris), International Center of Optical Astronomy (Shanghai).

Between 1980 and 1983, the Observatory participated in the MERIT campaigns.

After 1990 the observations stopped. We continue the theoretical studies concerning the Earth's rotation. 